\title{
KAJIAN WAKTU PENYELESAIAN METODE CRANE DAN METODE LAUNCHER DALAM PELAKSANAAN ERECTION GIRDER JEMBATAN \\ (Studi Kasus : Pembangunan Jalan Tol Semarang - Solo Ruas Salatiga - Boyolali Sta 40+409 - Sta 71+785)
}

\author{
Farouq Khoirul Izza ${ }^{1, *)}$, M. Ariya Praditama ${ }^{1)}$, Claudia Nimas \\ Kirana $^{1)}$, Karnawan Joko Setiyono ${ }^{1)}$, Sudarmono ${ }^{1)}$ \\ ${ }^{1)}$ Jurusan Teknik Sipil Politeknik Negeri Semarang \\ Jl. Prof. Soedarto SH, Tembalang Semarang 50275 Telepon (024) 76480569 \\ ${ }^{*}$ Email: farouqizza@gmail.com
}

\begin{abstract}
The Semarang-Solo Toll Road Project for the Salatiga-Kartasura Section is one part of the Trans Java toll road development project, one of the jobs in the form of an erection girder with the method used, namely the Crane and Launcher methods. The purpose of this study is to compare the completion time between Crane and Launcher Methods with field studies and analysis. Stages of research include literature studies, primary data collection in the form of variable time of completion and secondary data then analyzed by comparing the completion time of the second method of erection girder on girder with a span of 20.8 meters and 40.8 meters. The results of the comparison of completion time were obtained on a 20.8 meter span erection girder seen from the shortest time Crane Method was more efficient 61.44\% than the Launcher Method, the longest time Crane Method was more efficient $32.13 \%$ of the Launcher Method, and Method average time Crane is more efficient $52.15 \%$ than the Launcher Method. Then on the span erection girder 40.8 $m$ seen from the shortest time Crane Method is more efficient $61.48 \%$ than the Launcher Method, the longest time Crane Method is more efficient 29.82\% than the Launcher Method, and the average time of the Crane Method is more efficient 41, $81 \%$ of the Launcher Method
\end{abstract}

Kata kunci : erection girder, precast girder, crane method, launcher method

\section{PENDAHULUAN}

Semakin tingginya pertumbuhan penduduk di Indonesia harus diimbangi dengan sarana transportasi yang memadai, salah satu upaya untuk memenuhi kebutuhan transportasi darat yaitu dengan pembangunan jalan Tol SemarangSolo Ruas Salatiga-Kartasura STA 40+409 s.d 71+875 yang merupakan salah satu bagian dari proyek
Pembangunan Jalan Tol Trans Jawa. Tistogondo (2004) dalam penelitiannya tersebut didapat kesimpulan bahwa metode Roller Skate lebih cocok untuk diaplikasikan dilihat dari biaya yang dikeluarkan serta didapatkannya keuntungan dari aspek non kuantitatif, walaupun dari segi waktu metode Roller Skate pengerjaannya lebih lama daripada metode Crawler 
Crane.

Penelitian yang dilakukan Pratama (2013) menghasilkan analisa perbandingan antara Metode Erection Girder Menggunakan Launcher Girder dan Temporary Bridge pada Jembatan Kali Surabaya Mojokerto, yang ditinjau dari segi perhitungan biaya dan waktu. Sehingga dari beberapa alternatif didapat hasil yang paling optimal untuk pekerjaan erection girder jembatan kali surabaya proyek jalan tol Surabaya Mojokerto seksi 4 adalah dengan metode launcher girder dengan biaya sebesar Rp.996.000.000,00 dan waktu pelaksanaan 48 hari. Husein dan Dinariana (2013) dalam penelitiannya tersebut didapat hasil analisa dari segi waktu, metode kerjanya, dan biaya, Gantry Launcher lebih unggul waktu dan metode kerjanya dari Mobile Crane, sedangkan untuk analisa biaya Mobile Crane lebih unggul dari Gantry Launcher. Octario (2015) hasil analisis penelitian ini menunjukkan bahwa produktivitas erection girder dengan menggunakan metode gantry launcher pada segmen A1-P1 didapat durasi waktu selama 17 hari kerja dan pelaksanaan erection girder meliputi pekerjaan pelangsiran girder, stressing girder, grouting girder dan erection girder.

Permadani (2016) hasil dari penelitian ini adalah pelaksanaan Pekerjaan utama dari erection PCI girder dengan menggunakan gantry launcher adalah, pekerjaan pendahuluan, mobilisasi PCI girder, stressing PCI girder dan erection girder. Produktivitas erection PCI girder menggunakan alat gantry launcher pada P1-P2 (pier head 1 ke pier head 2) sebelah kanan underpass kereta api dengan panjang bentang 42 meter membutuhkan waktu 5 hari kerja untuk 11 span PCI girder. Sedangkan pada penelitian ini akan dilakukan perbandingan antara dua metode yaitu Metode Launcher dengan Metode Crane dari segi waktu penyelesaian erection girder pada beberapa jembatan, dengan material yang digunakan berupa $I$ girder sesuai dengan pengamatan di lapangan.

\section{METODE PENELITIAN \\ Studi Pustaka}

Studi pustaka yaitu identifikasi latar belakang dan perumusan masalah, serta mempelajari teori-teori terkait penelitian. Tujuan dari studi pustaka adalah untuk mencari teori-teori, konsep-konsep dan hasil-hasil penelitian dahulu (empririk) yang relevan dengan masalah penelitian yang akan dibahas.

\section{Pengambilan Data}

Dalam penelitian ini peneliti mengambil data pada Proyek Jalan Tol Boyolali - Kartasura sta. $58+500$ - sta.71+875. Data yang dibutuhkan dapat berupa data sekunder maupun data primer.

1. Data Sekunder meliputi:
a. Layout Jembatan
b. Spesifikasi gelagar (girder)
c. Kapasitas alat

2. Data Primer

Data yang diperoleh dari 
penelitian dilapangan pada Proyek Tol Semarang-Solo Ruas SalatigaKartasura STA 40+409 s.d 71+875 yaitu berupa waktu siklus dari setiap masing-masing metode erecrtion girder dengan 1 Crane, 2
Crane dan Launcher pada beberapa jembatan yang diamati. Waktu penyelesaian Metode Crane dan waktu penyelesaian Metode Launcher dapat dilihat pada Tabel 1 dan 2 .

Tabel 1. Uraian waktu penyelesaian Metode Crane

\begin{tabular}{clc}
\hline No & \multicolumn{1}{c}{ Uraian } & Waktu \\
\hline 1. & Pemasangan sling ke girder & $\mathrm{T} 1$ \\
2. & Pelepasan bracing girder & $\mathrm{T} 2$ \\
3. & Pengangkatan girder & $\mathrm{T} 3$ \\
4. & Penggeseran/pemutaran(swing) girder & $\mathrm{T} 4$ \\
5. & Penurunan/perletakan girder ke bearing pad & $\mathrm{T} 5$ \\
6. & Bracing girder & $\mathrm{T} 6$ \\
7. & Pelepasan sling & $\mathrm{T} 7$ \\
8. & Crane kembali ke posisi awal & $\mathrm{T} 8$ \\
\hline \multicolumn{2}{c}{ Waktu penyelesaian total Crane } \\
\hline
\end{tabular}

Tabel 2. Uraian waktu penyelesaian Metode Launcher

\begin{tabular}{llc}
\hline No & \multicolumn{1}{c}{ Uraian } & Waktu \\
\hline 1. & Pemasangan sling Hoist Laucher 1 & $\mathrm{T} 1$ \\
2. & Pelepasan bracing trolley launching 1 & $\mathrm{T} 2$ \\
3. & Launching girder ke hoist launcher & $\mathrm{T} 3$ \\
4. & Pemasangan sling hoist launcher 2 & $\mathrm{T} 4$ \\
5. & Pelepasan bracing trolley launching 1 & $\mathrm{T} 5$ \\
6. & Penurunan sampai 10 cm diatas bearing pad & $\mathrm{T} 6$ \\
7. & Launching girder ke posisi bentang & $\mathrm{T} 7$ \\
8. & Penggeseran launcher & $\mathrm{T} 8$ \\
9. & Perletakan girder & $\mathrm{T} 9$ \\
10. & Bracing girder & $\mathrm{T} 10$ \\
11. & Pelepasan sling & $\mathrm{T} 11$ \\
12. & Hoist launcher kembali ke posisi awal & $\mathrm{T} 12$ \\
\hline & Waktu penyelesaian total Launcher & $\mathrm{TTc}$ \\
\hline
\end{tabular}

\section{Analisa Data}

Analisa dilakukan dengan mencari waktu terpendek, waktu terpanjang, dan waktu rata-rata erection girder dari masing-masing metode. Waktu terpendek adalah waktu dimana kondisi produktivitas tinggi, sedangkan waktu terpanjang adalah waktu dimana kondisi produktivitas rendah dan waktu rata-rata adalah waktu dimana kondisi produktivitas rata-rata pada satu jembatan maupun 
lingkup metode, kemudian dihitung efisiensinya terhadap waktu terlama antara satu metode dengan metode lainnya. Rumus efisiensi terhadap waktu terlama ini merupakan modifikasi/penyesuaian dari rumus yang digunakan oleh Husein dan Dinariana (2013). Rumus yang telah disesuaikan adalah sebagai berikut:

$\mathrm{W}=(\mathrm{C} / \mathrm{L}) \times 100 \%$

$\mathrm{E}=((\mathrm{L}-\mathrm{C}) / \mathrm{L}) \times 100 \%$ atau $\mathrm{E}=100 \%$

$-\mathrm{W}$.... (1)

Dimana :

$\mathrm{W}=$ Peresentase perbandingan waktu yang dibutuhkan terhadap

waktu terlama (\%)

$\mathrm{E}=$ Efisiensi $(\%)$

$\mathrm{C}=$ Waktu yang

dibutuhkan metode

tercepat (detik)

$\mathrm{L}=$ Waktu yang

dibutuhkan metode

terlama (detik)

\section{HASIL DAN PEMBAHASAN}

Jembatan pada proyek jalan tol Tol Boyolali - Kartasura sta.58+500 sta. 71+875 menggunakan girder sebagai struktur utamanya. Bentang setiap jembatan memiliki panjang girder yang bervariasi, yaitu $16,6 \mathrm{~m}$, 20,8 m, 30,8 m, 40,8 m, dan 45,8 m. Metode pelaksanaan proyek konstruksi yang baik apabila memenuhi persyaratan teknis, ekonomis (biaya murah, wajar, efisien), nonteknis, dan merupakan alternatif/pilihan terbaik (Syah 2004). Metode tersebut diantaranya adalah Metode Crane dan Metode Launcher. Dalam penelitian ini peneliti memilih Jembatan Kali Putih 1 dengan bentang 20,8 m (Metode Crane), Jembatan Sungai Grenjeng bentang 20,8 m (Metode Crane), Jembatan Sungai Plered dengan bentang 40,8 m (Metode Crane), Overpass Barukan dengan bentang 40,8 $\mathrm{m}$ (Metode Crane), dan Jembatan Sungai Putih dengan bentang 20,8 m (Metode Launcher) serta bentang 40,8 m (Metode Launcher).

\section{Metode Crane}

Metode Crane adalah suatu cara atau metode yang digunakan dalam pelaksanaan erection girder atau pemasangan girder dengan bantuan alat Crane. Berdasarkan jumlah alat Crane yang digunakan, metode ini dibagi lagi menjadi 2 yaitu Metode Erection dengan 1 Crane dan Metode Erection dengan 2 Crane.

1. Metode erection girder dengan 1 Crane

Erection girder dengan 1 Crane dilakukan pada bentang girder kurang dari sama dengan $(\leq)$ 20,8 meter. Dalam metode erection girder dengan 1 Crane ini, Crane dapat mengambil secara langsung girder dari stockyard untuk dierection, dengan catatan lokasi stockyard tidak lebih dari (>) 50 meter dari tepi abutment. Metode ini dapat diterapkan pada model jembatan apapun. Namun bila berupa overpass, tinggi pijakan Crane ke dudukan girder (bearing pad pada pier head) tidak boleh lebih dari 5 meter. Dalam metode erection girder dengan 1 Crane ini, 
Crane perlu dibantu dengan spreader beam untuk menghindari terjadinya tekuk pada girder.

2. Metode erection girder dengan 2 Crane

Erection girder dengan 2 Crane dilakukan pada bentang girder lebih dari (>) 20,8 meter. Pada erection girder dengan 2 Crane ini posisi girder harus berada di antara atau disamping dengan syarat masih dalam jangkauan kedua Crane. Sehingga perlu dilakukannya mobilisasi girder untuk jembatan model underbridge atau underpass karena jembatan tersebut melewati bisa jurang/sungai/lalulintas dan dibutuhkannya jembatan sementara untuk akses mobilisasi dengan Truck Bogie. Adapun model jembatan yaitu overpass, yang tidak dibutuhkan mobillisasi karena stockyard girder bisa didudukan di antara abutment-abutment/pilarpilar/abutment-pilar, sehingga kedua Crane bisa langsung dapat melakukan erection. Untuk model overpass, syarat tinggi pijakan Crane ke dudukan girder (bearing pad pada pier head) tidak lebih dari 5 meter.

\section{Metode Launcher}

Metode erection girder dengan Launcher adalah suatu cara atau metode yang digunakan dalam pelaksanaan erection girder atau pemasangan girder dengan bantuan alat Launcher. Metode ini mampu di terapkan pada model jembatan apapun dan tanpa jalan akses. Launcher dalam proses erection ini hanya diperuntukkan untuk melakukan geser ke arah melintang jembatan. Sehingga Launcher tidak bisa langsung mengambil girder dari stockyard dan dibutuhkan mobilisasi girder. Alat bantu mobilisasi dalam metode Launcher menurut PT. Jatra Sejahtera (2018) adalah dengan Trolley Launching yang didudukkan pada lintasan rel yang dibangun sepanjang stockyard sampai dengan tepi abutment/pilar sehingga Launcher dapat menjangkau girder dan melakukan erection.

\section{Erection Jembatan Kali Putih (Metode Crane)}

Jembatan Kali Putih 1 terletak di STA. 61+331 pada Proyek Pembangunan jalan Tol SemarangSolo Ruas Salatiga-Kartasura. Jembatan ini terdiri dari beberapa bentang yaitu bentang antara Abutment 1-Pilar 1, Pilar 1-Pilar 2, Pilar 2- Pilar 3, dan Pilar 3-Abutment 2. Pilar 2 didesain menjadi 2 bagian yang terpisah dengan maksud untuk menyesuaikan arah aliran sungai, sehingga ada Pilar 2A dan Pilar 2B. Layout jembatan Kali putih 1 dapat di lihat pada Gambar 1 : 


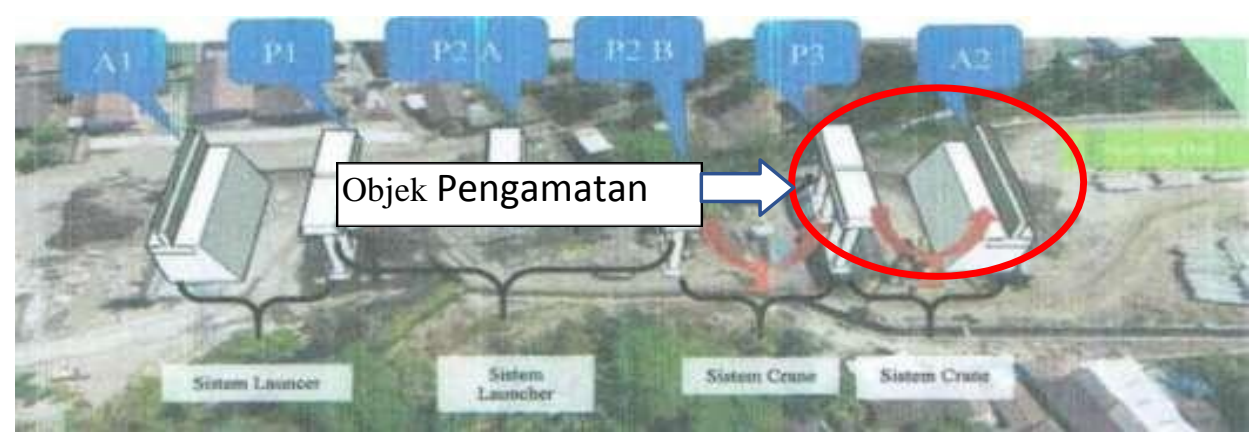

Gambar 1. Layout Jembatan Kali Putih 1

Dalam penelitian ini peneliti memungkinkan Crane untuk mengamati pelaksanaan erection girder pada bentang $\mathrm{P} 3-\mathrm{A} 2$ yang memiliki bentang 20,8 meter dengan berat girder 22,94 ton. Pada bentang tersebut digunakan metode dengan 1 buah Crane berkapasitas lifting yaitu 250 ton. Lokasi stockyard girder bentang P3-A2 berada \pm 30 meter dari tepi abutment, sehingga mengambil girder langsung dari stockyard menuju area erection girder dan langsung melakukan erection tanpa adanya mobilisasi dengan Truck Bogie. Sketsa tampak samping dan tampak atas situasi awal pelaksanaan erection girder Jembatan Kali Putih 1 bisa dilihat pada Gambar 2.

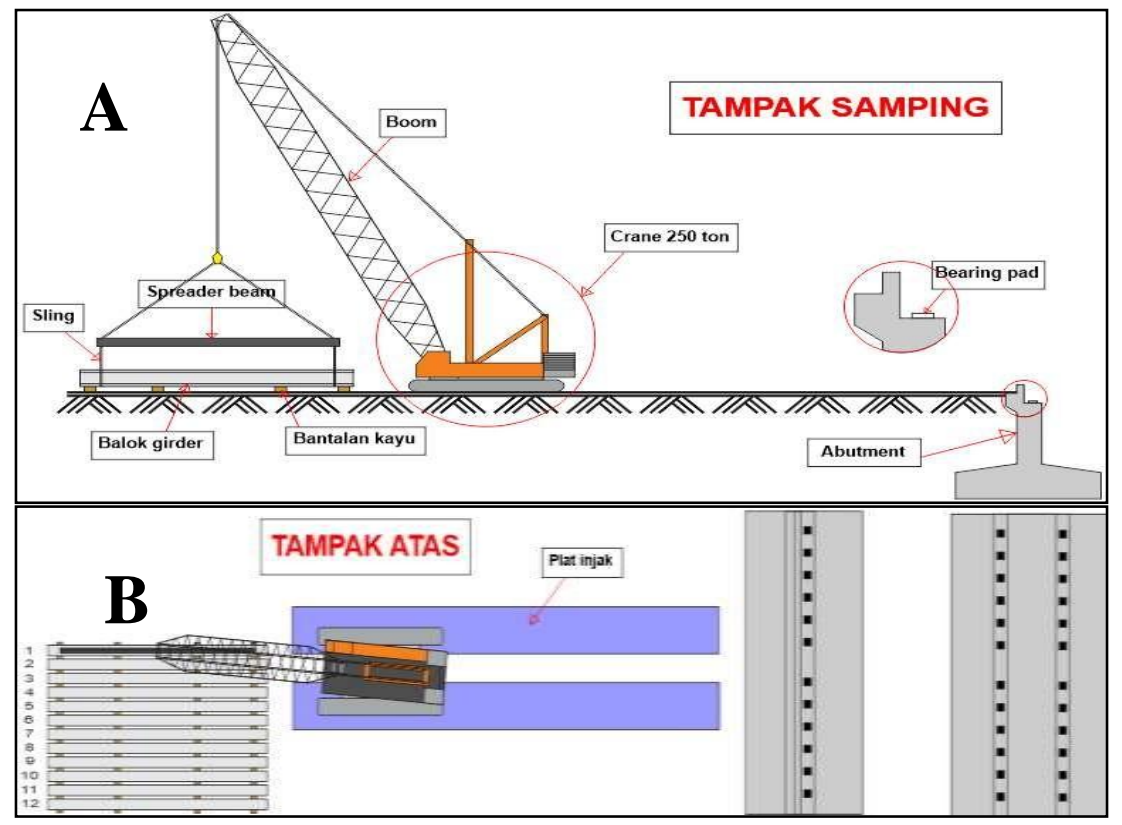

Gambar 2. Sketsa tampak samping (a) dan tampak atas (b) situasi awal pelaksanaan erection girder Jembatan Kali Putih 1 
Erection Jembatan Sungai Putih

Jembatan Sungai Putih terletak di STA. 55+522.541 pada Proyek Pembangunan jalan Tol SemarangSolo Ruas Salatiga-Kartasura. Jembatan ini terdiri dari beberapa bentang yaitu bentang antara Abutment 1 - Pilar 1, Pilar 1 - Pilar 2, dan Pilar 2 - Abutment 2. Layout Jembatan Sungai Putih dapat dilihat pada Gambar 3.

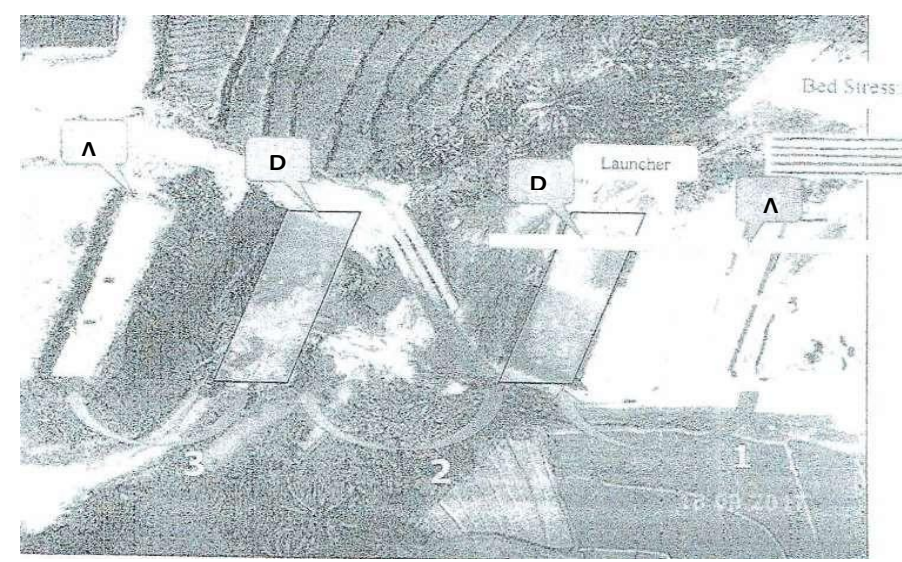

Gambar 3. Layout Jembatan Sungai Putih

Dalam penelitian ini peneliti mengamati pelaksanaan erection girder pada bentang $\mathrm{P} 2-\mathrm{A} 2$ dengan panjang 20,6 meter dan berat girder 21,9 ton (12 buah), serta bentang P1-P2 dengan panjang 40,8 meter dan berat girder 80,53 ton (12 buah). Pada kedua bentang tersebut digunakan metode dengan Launcher berkapasitas 120 ton.

Pada Jembatan Sungai Putih ini lokasi stockyard girder berada di belakang abutment 1 (A1). Sebelum penerapan metode Launcher, pada bentang A1-P1 dengan panjang 20,6 meter dan berat 21,9 ton sudah dierection menggunakan metode erection girder dengan 1 Crane. Kombinasi ini dimaksudkan untuk mempercepat pelaksanaan erection di Jembatan Sungai Putih. Selanjutnya untuk pelaksanaan erection dengan Launcher ini, lebih dahulu bentang P2-A2 yang dierection dan selanjutnya bentang P1-P2. Situasi tampak samping dan tampak atas dalam pelaksanaan erection girder Jembatan Sungai Putih dapat dilihat pada Gambar 4 dan 5 di bawah.

Tahapan pelaksanaan di lapangan :

1. Melepas bracing Trolley Launching 1

2. Launching girder hingga girder bagian belakang mampu dijangkau hoist Launcher 2

3. Memasang sling Hoist Launcher 2 pada girder bagian belakang

4. Melepas bracing Trolley Launching 2

5. Melakukan launching girder menuju posisi bentang A2 - P2 (untuk bentang 20,8 m) dan P1 P2 (untuk bentang 40,8 m) 
6. Menurunkan girder hingga $10 \mathrm{~cm}$ di atas bearing pad

7. Menggeser girder menuju koordinat yang sudah ditentukan

8. Menurunkan girder ke bearing pad

9. Melakukan bracing girder pada abutmen/pilar dan antar girder

10. Melepas sling kedua Hoist Launcher

11. Launcher beserta hoist-nya kembali ke posisi awal

Launcher kembali dengan melakukan geser. Sedangkan kedua Hoist kembali launching menuju posisi pengambilan girder.

\section{Analisa Data Waktu Penyelesaian Erection Girder bentang $20,8 \mathrm{~m}$ Metode Crane}

Dalam pelaksanaan erection girder bentang 20,8 m dengan Metode Crane ini digunakan 1 buah alat Crane. Jembatan yang mempunyai bentang 20,8 m dengan Metode Crane adalah Jembatan Kali Putih 1 dan Jembatan Sungai Grenjeng. Dalam analisa data waktu ini meliputi penjumlahan waktu semua uraian pekerjaan pada masing-masing girder, mencari waktu terpendek dan terpanjang, serta waktu rata-rata. Analisa data waktu penyelesaian erection girder dengan 1 Crane Jembatan Kali Putih 1 dan Jembatan Sungai Grenjeng bentang 20,8 meter. Hasil analisa data waktu dari kedua jembatan didapat batas waktu penyelesaian terpendek dan terpanjang Metode Crane untuk erection girder bentang 20,8 meter adalah 27 menit 9 detik dan 56 menit 26 detik, dengan rata-rata yaitu 37 menit 12 detik.

\section{Analisa Perbedaan Skematik Data Waktu}

Skematik lama waktu erection setiap girder pada jembatan satu dengan lainnya padahal dengan metode yang sama serta posisi girder yang telah disesuaikan hingga mirip (paling mendekati) terjadi perbedaan cukup signifikan ini dapat dikarenakan oleh beberapa faktor penyebab pada saat proses erection girder. Faktor penyebab tersebut diantaranya sebagai berikut:

1. Kondisi alam yang tidak mendukung,

2. Ketidak-sesuaian prosedur pelaksanaan oleh pelaksana,

3. Produktivitas kerja yang rendah akibat kelelahan tenaga kerja.

\section{Analisa Perbandingan Waktu Penyelesaian Metode Crane dengan Metode Launcher}

Setelah didapat waktu terpendek, terpanjang dan rata-rata erection girder pada Metode Crane dan Metode Launcher, kemudian dilakukan perbandingan efisiensi waktu sesuai kondisi bentang yang sama. 


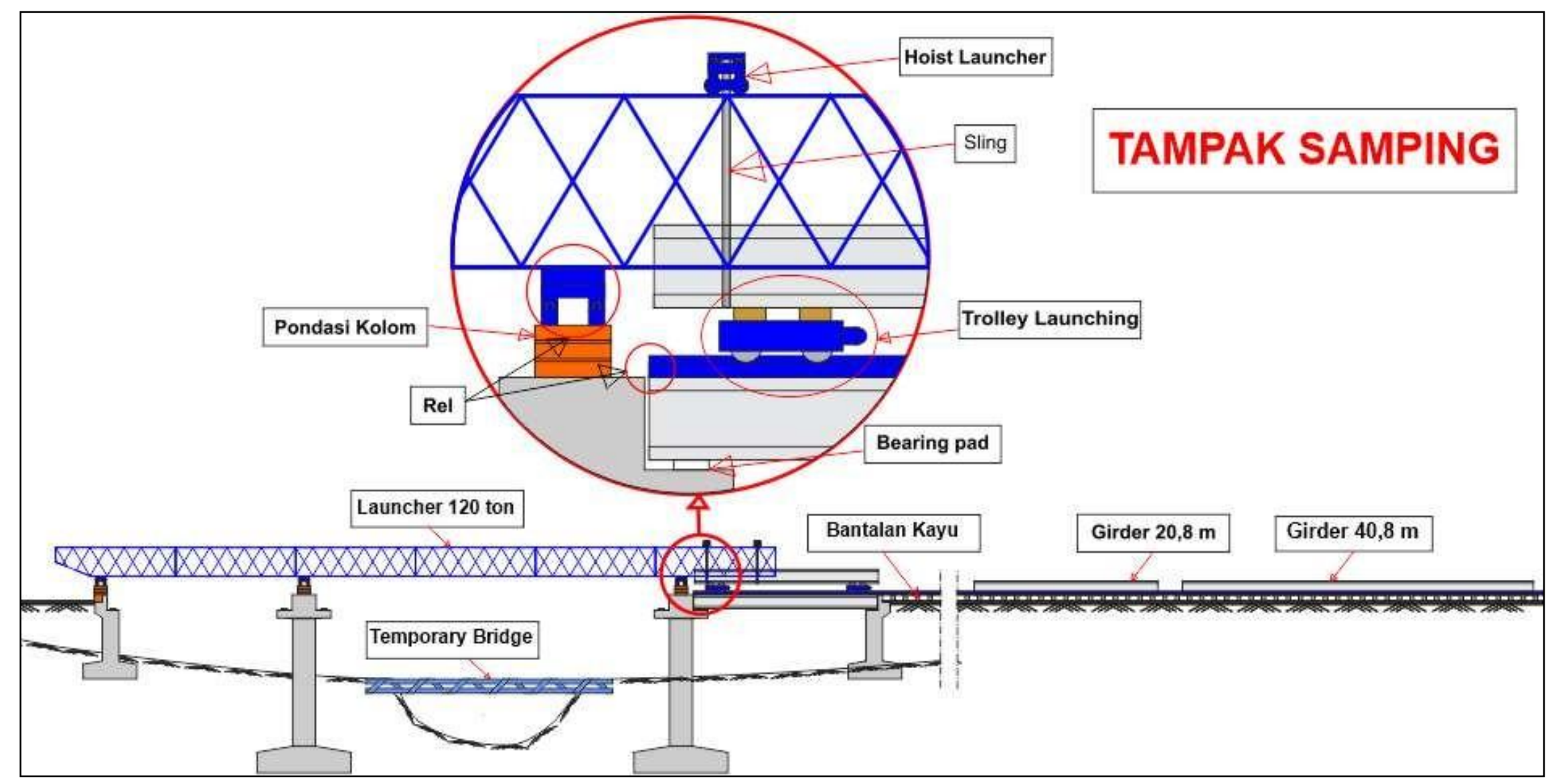

Gambar 4. Sketsa situasi tampak samping awal pelaksanaan erection girder Jembatan Sungai Putih 


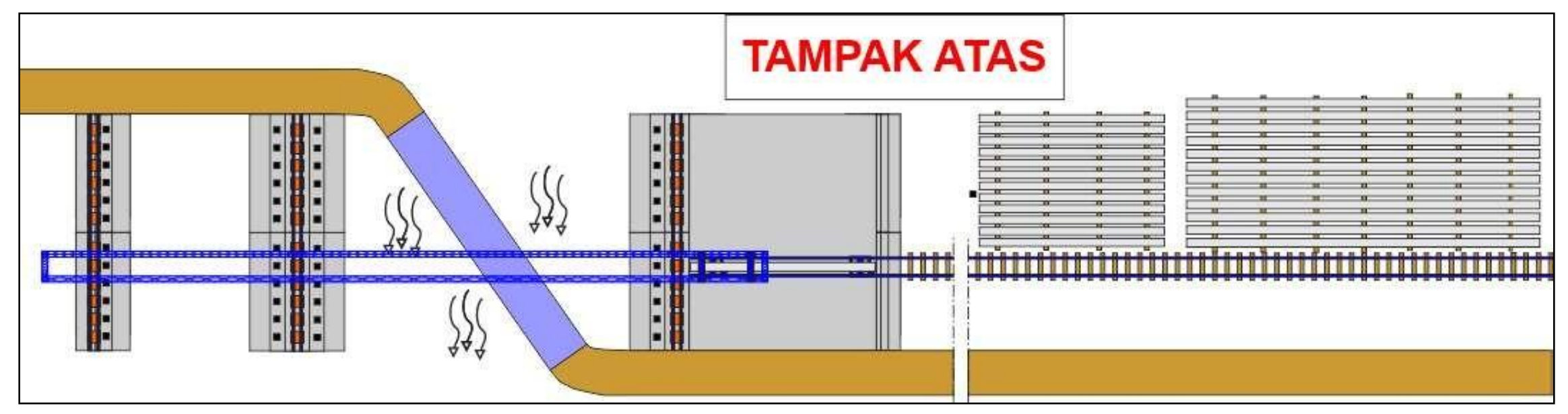

Gambar 5. Sketsa situasi tampak atas awal pelaksanaan erection girder Jembatan Sungai Putih (lanjutan) 
Contoh perhitungan efisiensi terhadap waktu terlama antara waktu terpendek Metode Crane dengan Launcher dalam erection girder bentang 20,8 m:

$\mathrm{C}=27$ menit 9 detik $=1629$ detik

$\mathrm{L}=1$ jam 10 menit 25 detik $=4225$

$\operatorname{detik} \mathrm{W}=(1629 / 4225) \times 100 \%$

$=38,56 \%$

$\mathrm{E}=((4225-1629) / 4225) \times 100 \%$

$=61,44 \%$

Dari hasil perhitungan tersebut diperoleh hasil sebagai berikut:

1. Dalam erection girder bentang 20,8 $\mathrm{m}$

Waktu terpendek Metode Crane lebih efisien $61,44 \%$ dari waktu terpendek Metode Launcher.

Waktu terpanjang Metode Crane lebih efisien 32,13\% dari waktu terpanjang Metode Launcher.

Waktu rata-rata Metode Crane lebih efisien 52,15\% dari waktu rata-rata Metode Launcher.

2. Dalam erection girder bentang $40,8 \mathrm{~m}$

Waktu terpendek Metode Crane lebih efisien $61,48 \%$ dari waktu terpendek Metode Launcher.

Waktu terpanjang Metode Crane lebih efisien 29,82\% dari waktu terpanjang Metode Launcher.

Waktu rata-rata Metode Crane lebih efisien $41,81 \%$ dari waktu rata-rata Metode Launcher.

\section{Analisa Perbandingan Metode Crane Dan Metode Launcher Secara Kualitatif}

Dalam pengerjaannya, Metode Crane relatif kurang stabil karena alat utama melakukan perpindahan bisa ke segala arah serta landasan gerak berupa plat yang digelar pada tanah (CBR min. 6 $\%)$ atau dapat berupa lantai kerja. Sedangkan Metode Launcher relatif lebih stabil karena alat utama melakukan perpindahan hanya satu arah serta landasan gerak berupa lintasan rel yang rata. Dalam memberikan dampak pada lingkungan, Metode Crane (terutama pada erection dengan dua Crane) membutuhkan lahan yang lebih untuk keperluan akses girder sehingga Crane mampu menjangkau girder untuk dapat di-erection. Sedangkan pada Metode Launcher, girder tidak dibutuhkan akses tambahan.

Dalam kemampuan diterapkannya, Metode Crane dengan Metode Launcher sama-sama dapat diterapkan pada kondisi jembatan model overpass, underpass, ataupun underbridge. Namun pada kondisi jembatan model underpass maupun underbridge jika tidak ada akses tambahan baik di bawah maupun disamping jembatan yang akan dierection Metode Crane tidak dapat diterapkan, sedangkan Metode Launcher tetap dapat diterpakan. Dalam kapasitas angkatnya, Metode Crane terdapat penurunan kapasitas angkat sesuai radius lengan (boom). Sedangkan Metode Launcher kapasitas angkat tidak terjadi penurunan. Perbandingan Metode Crane dan Metode Launcher Secara Kualitatif dapat dilihat pada Tabel 3 berikut. 
Tabel 3. Perbandingan Metode Crane dan Metode Launcher Secara Kualitatif

\begin{tabular}{lll}
\hline No & \multicolumn{1}{c}{ Metode Crane } & \multicolumn{1}{c}{ Metode Launcher } \\
\hline 1 & Relatif kurang tabil & Relatif lebih stabil \\
2 & Butuh lahan lebih untuk akses & Tidak butuh tambahan lahan \\
3 & Dapat diterapkan pada kondisi & Dapat diterapkan pada kondisi \\
& jembatan tertentu & jembatan bagaimanapun \\
4 & Ada penurunan kapasitas angkat & Tidak ada penurunan kapasitas angkat \\
\hline
\end{tabular}

\section{SIMPULAN}

Pada erection girder bentang 20,8 meter dilihat dari waktu terpendek Metode Crane lebih efisien 61,44\% daripada Metode Launcher, waktu terpanjang Metode Crane lebih efisien 32,13\% daripada Metode Launcher, dan waktu rata-rata Metode Crane lebih efisien $52,15 \%$ daripada Metode Launcher. Kemudian pada erection girder bentang 40,8 m dilihat dari waktu terpendek Metode Crane lebih efisien 61,48\% daripada Metode Launcher, waktu terpanjang Metode Crane lebih efisien 29,82 \% daripada Metode Launcher, dan waktu rata-rata Metode Crane lebih efisien 41,81 \% daripada Metode Launcher. Hasil dari penelitian ini menunjukkan bahwa dari segi waktu penyelesaian erection girder, Metode Crane lebih cepat (efisien) daripada Metode Launcher.

\section{DAFTAR PUSTAKA}

Husein, W.S, Dinariana, D., 2013, Perbandingan Gantry Dan Mobile Crane Pada Jalan Layang Dari Segi Waktu, Metode Kerja, Dan Biaya. https://www. google.com/ url?sa=t\&rct $=\mathrm{j} \& \mathrm{q}=$ \&esrc $=$ s\&source $=, \quad(13$ Agustus 2018).

Octario, T., 2015, Metode
Pelaksanaan Dan Analisis

Produktivitas Gantry Launcher Pada Pekerjaan Erection Girder Proyek Flyover Palur, Tugas Akhir, Yogyakarta, Jurusan Teknik Sipil Universitas Gajah Mada.

Permadani, C.P., 2016, Metode Pelaksanaan Erection PCI Girder dan Analisis Produktivitas Menggunakan Alat Gantry Launcher pada Proyek Pembangunan Jalan Tol Surabaya-Mojokerto Seksi 1B. Tugas Akhir, Yogyakarta, Jurusan Teknik Sipil Universitas Gajah Mada.

Pratama , D.D., 2013, Analisa Perbandingan Metode Erection Girder Menggunakan Launcher Girder Dan Temporary Bridge Dari Segi Biaya Dan Waktu Pada Jembatan Kali Surabaya Mojokerto, JURNAL TEKNIK POMITS, Vol. 1, No. 1, Hal. 110.

PT. Jatra Sejahtera, 2018, Rev 1, Erection Girder Jembatan Sungai Putih Menggunakan Metode Launcher Crane, Jombang.

Syah, M.S., 2004, Manajemen Proyek Kiat Sukses Mengelola Proyek, 
Cetakan Pertama. Jakarta: Gramedia Pustaka Utama. Jombang.

Tistogondo, Julistyana, 2004, Studi Efektifitas Waktu dan Biaya Pelaksanaan Erection PCI
Girder dengan Metode Crawler Crane dan Roller Skate (Kasus: Proyek Pembangunan Jembatan Suramadu Sisi Surabaya), , Jurnal Neutron, Vol. 4, No. 1, Hal. 79-106. 